\title{
Pemanfaatan Infografis Dalam Gerakan Literasi Sekolah di SMK Katolik Kefamenanu
}

\author{
Maria Rosalinda Talan ${ }^{1)}$, Adeline Lelo Lein ${ }^{2)}$, Kristofel Bere Nahak ${ }^{3)}$ \\ Program Studi Pendidikan Bahasa dan Sastra Indonesia, Fakultas Ilmu Pendidikan \\ Unversitas Timor, Indonesia ${ }^{1,2), 3)}$ \\ Pos-el : maria_rosalindatalan@yahoo.co.id
}

Dikirim: 19, 05, 2020

Direvisi: 09, 07, 2020

Diterbitkan: 31, 08, 2020

\begin{abstract}
Abstrak
Berdasarkan observasi awal, pelaksanaan gerakan literasi sekolah (GLS) belum melibatkan media teknologi informasi. Padahal, era revolusi industri 4.0 menuntut masyarakat untuk menyesuaikan diri dengan segala perkembangan, salah satunya melalui penggunaan media digital. Oleh karena itu, tim pengabdi bertujuan melakukan pengabdian pendampingan pemanfaatan infografis dalam kegiatan literasi membaca sebagai jawaban tuntutan zaman tersebut. Pengabdian ini dilaksanakan di SMK Katolik Kefamenanu. Kegiatan ini meliputi tiga tahapan besar yakni 1) memperkenalkan, menjelaskan, dan mempraktikan desain infografis; 2) meminta peserta didik untuk membaca keunggulan objek Indonesia di Wikipedia, dan 3) melaporkan hasil baca melalui desain infografis. Hasil pengabdian ini menunjukkan bahwa pemanfaatan infografis dapat meningkatkan motivasi dan kreativitas peserta didik dalam kegiatan literasi membaca. Motivasi dan kreativitas peserta didik dapat diidentifikasi dari tingkat aktivitas peserta didik yang tinggi dan kemampuan berkreasi memilih fitur-fitur menarik dalam templat infografis yang sesuai keinginan peserta didik. Dengan demikian infografis ini dapat direkomendasikan untuk diterapkan dalam literasi membaca sebagai bagian dari GLS.
\end{abstract}

Kata Kunci: Infografis, Gerakan Literasi Sekolah, Membaca

\begin{abstract}
Based on initial observation, the implementation of the School Literacy Movement has not yet involved media information technology. In fact, the era of 4.0 Industrial Revolution requires people to adapt to all its development, one of them by using digital media. Therefore, the concerning community service team performs the devotion of mentoring by using infographics in reading literacy activities as an answer to the demands of the times. This dedication was held at SMK Katolik Kefamenanu . These activities include three major stagesof 1) introducing, explaining, and practicing infographic designs; 2) Asked students to read the excellence of Indonesian objects on Wikipedia, and 3) report the reading results through infographic design.These outcomes showed that using infographics can increase the motivation and creativity of students in reading literacy activities. Students'motivation and creativity can be identified from high level of student activity and creative ability to choose interesting features in infographic templates that suit students ' wishes. Therefore, this infographic can be recommended tobe applied in reading literacy as part of the School Literacy Movement.
\end{abstract}

\section{Keywords: Infographic, School Literacy Movement, Reading}

\section{PENDAHULUAN}

Era digital menjadikan aktivitas membaca memegang peranan penting. Kegiatan membaca melalui media digital mempercepat pemerolehan beragam informasi dari dalam maupun luar negeri. Selain itu, melalui kegiatan membaca dunia ilmu dapat dijelajahi dari berbagai penjuru dunia dan dari berbagai zaman. Kegiatan membaca juga membantu 
perkembangan diri seseorang dalam bidangnya masing-masing secara maksimal. Hal ini disimpulkan secara umum oleh Permatasari (2015) bahwa kualitas suatu bangsa ditentukan dengan budaya literasi (membaca).

Wierdarti dkk. (dalam Agustina, 2019) menjelaskan bahwa keterampilan memahami bacaan masyarakat Indonesia sangat memprihatinkan. Dalam PIRLS 2011 International Results in Reading, Indonesia menduduki peringkat ke-45 dari 48 negara dengan skor 428 dari skor rata-rata 500. Selain itu, dalam kompetisi literasi membaca dalam PISA 2009 menunjukkan peserta didik Indonesia berada pada peringkat ke-57 dengan skor 396 (skor rata-rata OECD 493), sedangkan PISA 2012 menunjukkan peserta didik Indonesia berada pada peringkat ke-64 dari 65 negara dengan skor 396 (skor ratarata OECD 496) (OECD, 2013). Riset UNESCO pada tahun 2012 mengenai kebiasaan membaca masyarakat Indonesia, menunjukkan bahwa hanya satu dari 1.000 orang masyarakat Indonesia yang membaca. Padahal menurut Agustina (2019) di pada abad ke-21, peserta didik diharapkan memiliki kreativitas dan inovasi (creativity and innovation), kemampuan berpikir kritis dan memecahkan masalah (critical thinking and problem solving), dapat berkomunikasi (communication), dan berkolaborasi (collaboration) sehingga bisa menghadapi tantangan zaman di masa depan.

Fenomena-fenomena yang terjadi di atas menunjukkan hasil kemampuan membaca masyarakat Indonesia belum memuaskan. Hal ini disebabkan karena adanya kendala di dalam proses pendidikan. Salah satu kendalanya adalah sekolah belum menjalankan perannya sebagai lembaga pendidikan yang dapat mengakomodasi peserta didik melakukan aktivitas membaca sebagai suatu kebiasaan sepanjang hayat atau yang disebut sebagai budaya membaca. Pada umumnya, pendidik sekadar mengajarkan membaca namun tidak membiasakan peserta didik untuk membaca. Kegiatan membaca yang tidak dibiasakan tidak akan menjadi kebudayaan. Dengan kata lain budaya membaca bersumber dari kebiasaan membaca.

Berdasakan kenyataan tersebut, pada tahun 2015 pemerintah dalam hal ini Kementerian Pendidikan dan Kebudayaan meluncurkan suatu kebijakan yakni Gerakan Literasi Sekolah (GLS). GLS merupakan sebuah upaya yang dilakukan secara menyeluruh untuk menjadikan sekolah sebagai organisasi pembelajaran yang warganya literat sepanjang hayat melalui pelibatan publik. Peraturan Menteri Pendidikan dan Kebudayan Nomor 23 Tahun 2015 menyatakan secara tertulis bahwa GLS merupakan sebuah program nasional yang dicanangkan dalam rangka menanamkan budi pekerti dan konsep pembelajaran sepanjang hayat. Dengan demikian, program ini dijalankan dalam rangka memciptakan budaya membaca.

Literasi membaca sebagai bagian dari GLS merupakan gerakan literasi wajib dilaksanakan setiap sekolah yang bertujuan untuk menumbuhkembangkan minat membaca dan membangun kemampuan berpikir kritis peserta didik. Selain itu, kegiatan ini dilaksanakan dengan tujuan meningkatkan keterampilan membaca agar pengetahuan dapat dikuasai secara lebih baik. Kegiatan dilakukan dengan cara peserta didik membaca buku nonpelajaran sebelum waktu belajar dimulai selama 15 menit. Materi baca berisi nilai-nilai budi pekerti, seperti kearifan lokal, nasional, dan global yang disampaikan sesuai tahap 
perkembangan peserta didik. Pujiono (2012) menyatakan bahwa upaya menumbuhkan literasi membaca dengan menerapkan kemampuan berpikir kritis dapat memperkuat jati diri bangsa.

Berdasarkan hasil observasi, program GLS dalam hal ini literasi membaca di SMK Katolik Kefamenanu sudah dijalankan namun masih mengalami permasalahan. Pendidik hanya berperan sebagai fasilitator dengan cara mengakomodasi kegiatan literasi membaca dari segi waktu dan tempat. Pelaksanaan membaca dilakukan selama 15 menit sebelum pelajaran dimulai dengan memanfaatkan buku yang terbatas yakni dari perpustakaan dan buku milik peserta didik sendiri. Setelah membaca, peserta didik diberikan tugas untuk melaporkan isi bacaan dengan cara menulis pada kertas yang disiapkan oleh peserta didik. Pendidik tidak menyiapkan Lembar Kerja Siswa (LKS) atau media lainnya dalam kegiatan tersebut. Dengan demikian, peserta didik merasa jenuh karena pelaksanaan GLS ini karena tidak mengakomodasi peserta didik untuk meningkatkan motivasinya. Hal ini ditegaskan oleh pendidik bahwa program GLS masih mengalami permasalahan yakni peserta didik kurang termotivasi dalam kegiatan membaca dan kreativitas peserta didik dalam melaporkan hasil baca masih rendah.

Permasalahan tersebut menjadi dasar tim pengabdi melakukan pengabdian dengan memanfaatkan infografis dalam GLS. Saptodewo (2014) menyatakan grafik informasi atau lebih dikenal dengan istilah infografis adalah salah satu bidang yang berkembang pesat dalam media massa setelah desainer yang dapat mengkombinasikan antara informasi dari ranah berita ke piranti lunak komputer yang mutakhir untuk menjelaskan cerita yang tidak dapat diceritakan oleh teks dan foto. Secara sederhana, infografis merupakan media penyampai informasi yang disajikan dalam bentuk grafis.

Infografis termasuk media penyampai informasi yang menarik karena tampilannya didesain menggunakan templatedan fitur-fitur yang tersedia sesuai keinginan pengguna. Selain berfungsi sebagai menarik perhatian, infografis juga berfungsi untuk memperjelas informasi, mengilustrasikan atau menghiasi fakta yang kemungkinan akan cepat dilupakan atau diabaikan bila tidak digrafiskan. Media grafis dapat berupa gambar/foto, video, diagram, bagan, dan grafik. Komponen-komponen ini disajikan bersama data/informasi singkat dan kompleks sehingga secara visual dapat menarik perhatian pembaca.

Dengan demikian, perlu dilakukan pelatihan pemanfaatan infografis sebagai media literasi membaca dalam GLS. Infografis digunakan pada saat peserta didik melaporkan hasil baca. Peserta didik tidak lagi menggunakan kertas, namun menggunakan infografis sebagai media digital agar lebih meningkatkan motivasi dan kreativitas peserta didik.

\section{METODE}

Kegiatan pengabdian pada mayarakat ini dilaksanakan di SMK Katolik Kefamenanu. Sasaran dalam pengabdian ini adalah peserta didik kelas XI-A dan XI-B Program Keahlian Multimedia. Pemilihan program tersebut memiliki alasan yakni peserta didik di program tersebut sudah terbiasa menggunakan perangkat computer sehingga meminimalkan hambatan dalam mengakses dan menggunakan media infografis. Peserta didik yang hadir sebanyak 40 orang yang diutus dari kedua kelas tersebut. Kegiatan dilakukan selama dua hari. Hari pertama dilakukan tahap pengenalan, sedangkan hari kedua dilakukan tahap aksi. 
Pelaksanaan kegiatan pengabdian pada masyarakat ini mengunakan metode ceramah, tanya jawab, dan praktik. Prosedur pelatihan pemanfaatan media infografis dilakukan dengan tahap 1) menjelaskan pentingnya kegiatan literasi; 2) memperkenalkan media infografis melalui aplikasi Canva; 3) menjelaskan cara penggunaan media infografis; 4) memberikan kesempatan kepada peserta didik untuk mendaftar dan mencoba mempraktikan desain infografis; 5) meminta peserta didik untuk membaca keunggulan objek Indonesia di Wikipedia; 6) meminta peserta didik untuk melaporkan hasil baca ke dalam media infografis; 7) meminta peserta didik menyimpan dan mengunduh infografis yang mereka buat; 8) meminta peserta didik mempresentasekan hasil baca dalam media infografis; dan 9) mengevaluasi program pelatihan pemanfaatan media desain infografis dalam GLS.

\section{HASIL DAN PEMBAHASAN}

Kegiatan pengabdian ini dilaksanakan selama dua hari. Pada hari pertama yakni tahap pengenalan, tim pengabdi datang ke sekolah berkoordinasi dengan kepala sekolah dan wali kelas XI-A dan XI-B Program Keahlian Multimedia untuk menyiapkan partisipan pengabdian. Setelah koordinasi, tim langsung masuk ke kelas untuk melaksanakan beberapa tahapan pengabdian yakni sebagai berikut. 1) Tim pengabdi menjelaskan tujuan pengadaan pelatihan kepada peserta didik. 2) Tim pengabdi menjelaskan pentingnya literasi sebagai salah satu upaya belajar sepanjang hayat dan meninggkatkan budi pekerti peserta didik melalui bacaan-bacaan yang positif. Dalam tahapan ini, tim juga menyarankan agar menggunakan media literasi digital dalam mengakses bacaan-bacaan yang terpercaya dan mengandung nilai-nilai moral atau berisi hal positif. Hal ini disarankan agar ada penyesuaian diri dengan era revolusi industri 4.0. 3) Tim pengabdi menjelaskan salah satu aplikasi yang dapat digunakan sebagai media laporan hasil baca dalam kegiatan literasi sekolah yakni aplikasi Canva yang lengkap dengan templat-templat seperti infografis, resum, poster, dan lain-lain. Tenyata, menurut peserta didik, mereka belum mengenal aplikasi tersebut. Oleh karena itu, tim pengabdi membentuk kelompok dan selanjutnya mendampingi peserta didik untuk mengakses aplikasi Canva baik dari HP Android maupun laptop. Setelah diakses, peserta didik didampingi tim pengabdi medaftar salah satu peserta didik dalam kelompok sebagai pengguna aplikasi tersebut melalui email dan facebook. Setelah itu, tim pengabdi memberi kesempatan kepada peserta didik untuk mengamati aneka desain dalam aplikasi Canva terkhususnya media infografis dan berlatih merevisi konten templatyang tersedia. Tujuannya agar peserta didik mengenal aplikasi tersebut lebih mendalam agar tidak kesulitan penggunaan

Hari yang kedua yakni tahap aksi, mengikuti tahapan berikut. 1) Tim pengabdi memasuki ruang kelas dan mengawali kegiatan dengan apersepsi. Apersepsi dimaksudkan untuk mengembalikan ingatan peserta didik mengenai literasi dan aplikasi Canva. 2) Tim pengabdi menjelaskan tugas yang akan dikerjakan yakni membaca keunggulan objek di Indonesia seperti Danau Kelimutu, Pulau Komodo, Kepulauan Raja Ampat, Kain Tenun NTT, dan lain-lain di laman Wikipedia selanjutnya melaporkan hasil baca melalui media infografis dalam aplikasi Canva. 3) Peserta didik dibagi ke dalam kelompok agar bisa saling berdiskusi menyelesaikan tugas tersebut. 4) Kegiatan inti dimulai melalui tahapan membaca keunggulan objek Indonesia di laman Wikipedia. Selanjutya peserta didik menyalin hal-hal 
penting dari bacaan ke media infografis dan memilih fitur-fitur seperti foto/gambar untuk memperindah tampilan laporan mereka. Selama kegiatan tersebut berjalan, tim pengabdi tetap mendampingi peserta didik yang masih kesulitan menjalankan aplikasi. 5) Setelah menyalin bacaan ke templat infografis, peserta didik mengunduh desain infografis karya mereka. 6) Selanjutnya tiap kelompok diberi kesempatan mempresentasikan laporan hasil baca mereka dalam desain infografis mereka. 7) Tim pengabdi memberi kesempatan kepada peserta didik untuk meyampaikan sikap mereka terhadap kegiatan laporan hasil baca melalui media infografis. Menurut peserta didik, aplikasi Canva sangat menarik sehingga memberikan motivasi yang tinggi untuk mendesain laporan hasil baca mereka dalam salah satu model desain dalam aplikasi Canva yakni media infografis. Kemenarikan tersebut terletak pada beragam templat dan fitur-fitur pendukung dalam aplikasi tersebut yang dapat memperindah tampilan suatu tulisan.

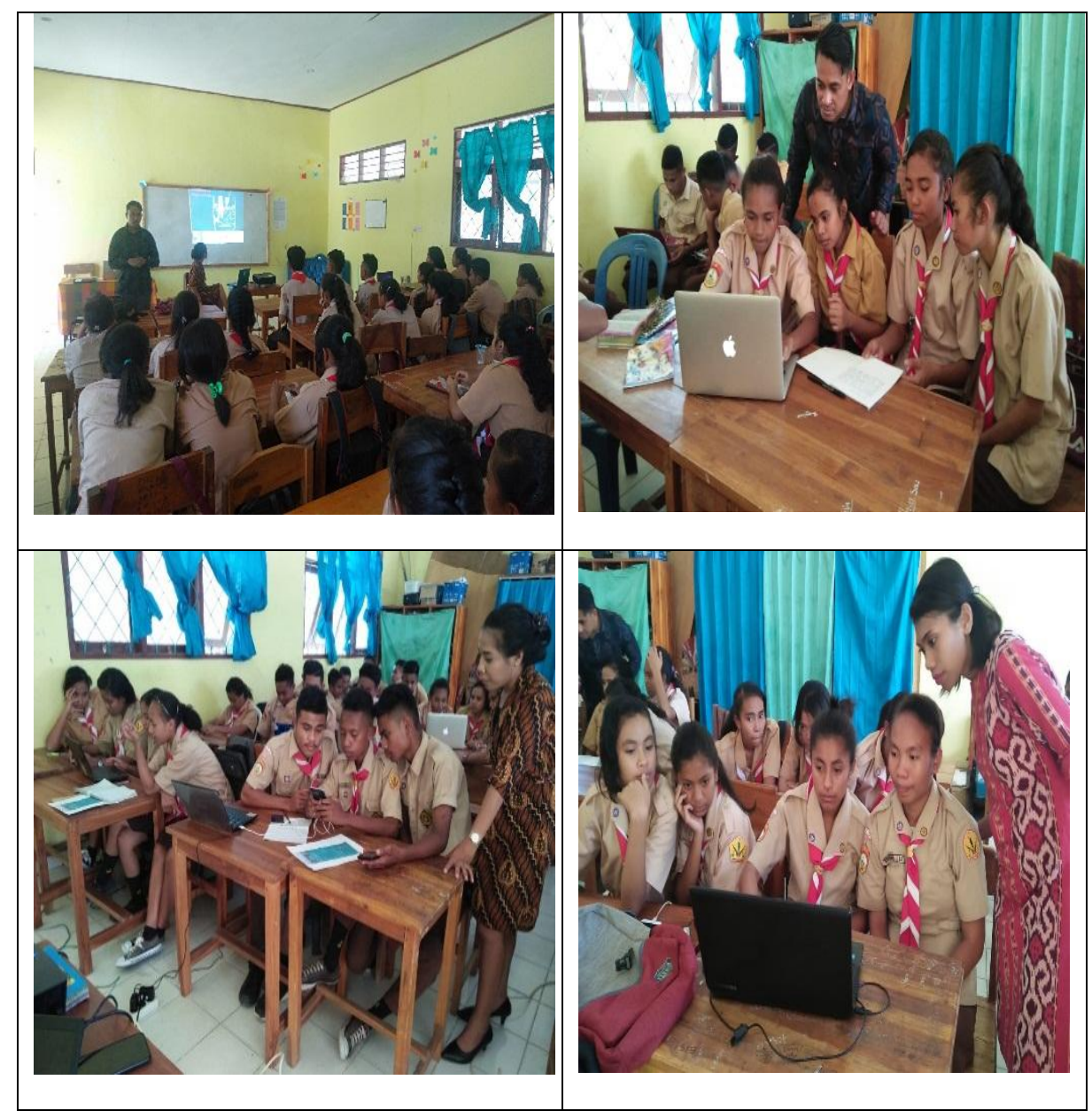

Gambar 1: Proses Pendampingan Desain Infografis dalam GLS

Berdasarkan observasi, peserta didik sangat antusias dalam kegiatan GLS yang menggunakan media infografis. Setiap siswa aktif mencari informasi dalam laman Wikipedia, selanjutnya menyalin hal-hal penting dari bacaan ke dalam media infografis. Adapun peserta didik yang masih kesulitan menggunakan aplikasi Canva, namun mereka aktif bertanya pula kepada tim pengabdi untuk dapat memecahkan masalah yang mereka hadapi. Setelah disalin, peserta didik mempresentasikan hasil desain mereka dengan penuh semangat. Beberapa hal ini menggambarkan adanya aktivitas peserta didik yang dominan. 
Dapat dikatakan bahwa motivasi peserta didik dalam kegiatan ini sangat baik karena didukung oleh adanya aktivitas peserta didik. Hal tersebut sejalan dengan pendapat Hamalik (2002:175) yang menyatakan bahawa motivasi merupakan suatu hal yang mendorong timbulnya suatu perbuatan, mengarahkan perbuatan kepada pencapaian tujuan yang dikehendaki. Perbuatan atau aktivitas peserta didik yang baik dalam kegiatan ini dapat mendorong pencapaian tujuan GLS yakni menumbuhkan minat baca peserta didik serta meningkatkan keterampilan membaca agar pengetahuan dapat dikuasai secara lebih baik.

Selain meningkatkan motivasi yang diidentifikasi dari aktivitas peserta didik, kegiatan ini juga memberi ruang kreativitas bagi peserta didik. Hal ini dibuktikan dari aktivitas peserta didik yang menggunakan fitur-fitur seperti gambar/foto yang diunduh untuk memperindah tampilan desain laporan hasil baca mereka. Jenis, ukuran, dan warna huruf pun digunakan peserta didik dengan komposisi yang seimbang sehingga memperindah tampilan. Selain itu, peserta didik dengan leluasa menambah maupun menguragi fitur-fitur dalam templat sesuai dengan keinginan mereka namun tetap mempertimbangkan aspek keindahan. Dengan demikian, templat desain infografis di aplikasi Canva ini membangkitkan kreativitas peserta didik untuk mengembangkan potensi diri mereka dengan cara melahirkan gagasan baru dalam produk tersebut. Hal ini mempertegas pendapat Rogers (dalam Munandar, 2009:18) yang menyatakan bahwa kreativitas memberikan kecenderungan untuk mengaktualisasi diri,

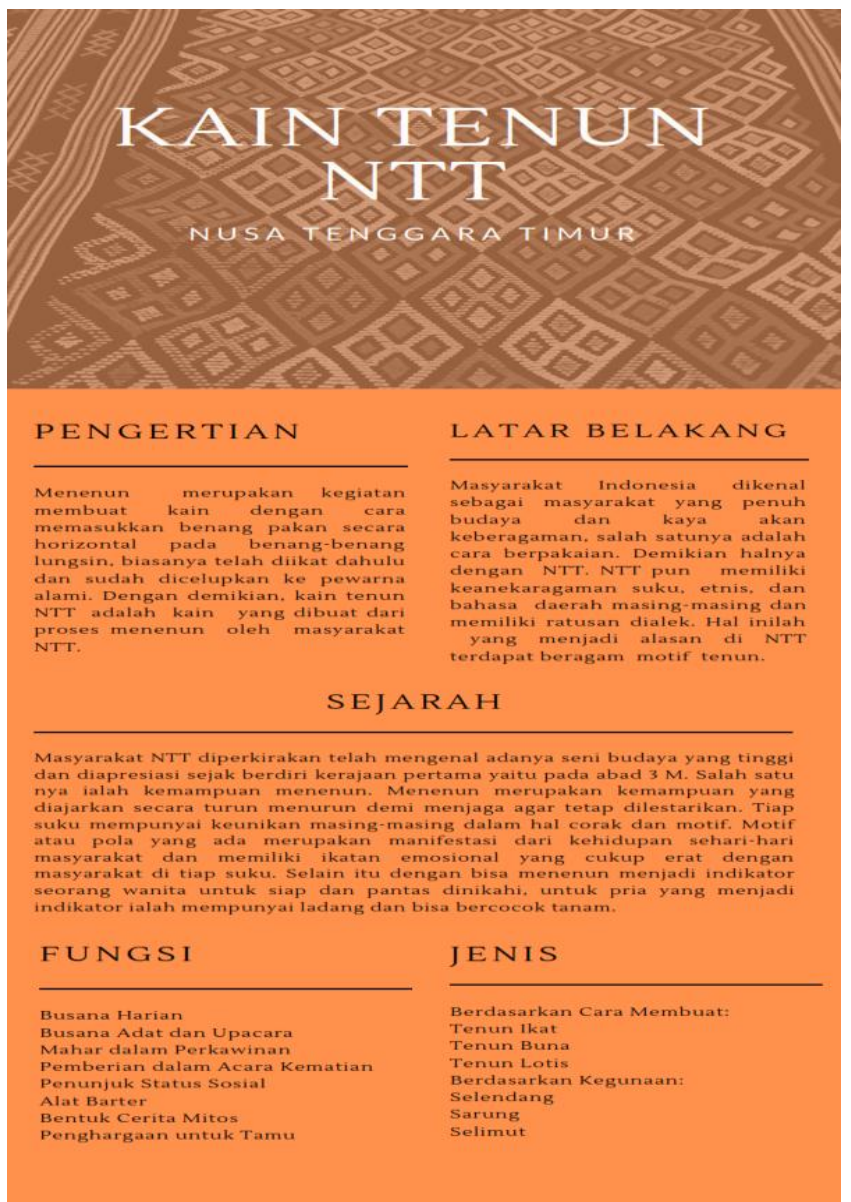

Gambar 2: Hasil Desain Infografis Peserta Didik dalam GLS 
mewujudkan potensi, dorongan untuk berkembang dan menjadi matang, kecenderungan untuk mengekspresikan dan mengaktifkan semua kemampuan.

Dengan demikian, aktivitas dan kreativitas peserta didik dalam kegiatan pendampingan GLS ini memberikan motivasi yang besar bagi peserta didik. Hal ini dikarenakan adanya pengalaman baru dalam cara melaporkan hasil baca dan memadukan gambar dan teks dalam templat desain infografis. Dampak ini sejalan dengan pendapat Susetyo dkk (2015) yang menjelaskan bahwa desain informasi yang menggabungkan antara teks dan gambar dapat dijadikan sebagai media belajar yang dapat meningkatkan semangat belajar siswa.

\section{SIMPULAN}

Lembaga Pendidikan merupakan salah satu wadah yang efektif untuk menanamkan budaya membaca kepada peserta didik. Oleh karena itu, upaya menumbuhkembangkan minat baca peserta didik dalam program GLS sangat bermanfaat. Namun, dalam pelaksanaan GLS perlu disesuaikan dengan perkembangan zaman. Hal ini dapat dilakukan dengan cara melibatkan media digital dalam program GLS. Media digital yang dapat digunakan adalah infografis yang dapat diakses pada aplikasi canva.

Penggunaan infografis melalui aplikasi canva yang dilakukan dalam kegiatan pengabdian pada masyarakat ini memberikan dampak positif. Dampak yang dimaksud adalah pemanfaatan media infografis dapat meningkatkan motivasi dan kreativitas peserta didik dalam kegiatan literasi. Motivasi dan kreativitas peserta didik dapat diidentifikasi dari tingkat aktivitas peserta didik yang tinggi dan kemampuan berkreasi memilih fitur-fitur menarik dalam templat infografis yang sesuai keinginan peserta didik. Dengan demikian media infografis ini dapat direkomendasikan untuk diterapkan dalam GLS.

\section{DAFTAR PUSTAKA}

Agustina, Noni. 2019. Desain Infograis: Pengembangan Kreativitas dan Literasi Membaca Siswa SD Hati Kudus. AbdiMas, 5 (3) : 186-190.

Hamalik, Oemar. 2002. Psikologi Belajar dan Mengajar. Bandung : Sinar Baru Algensindo.

Munandar, Utami. 2009. Pengembangan Kreativitas Anak Berbakat. Jakarta : PT Rineka Cipta.

Permatasari, Ane. 2015. Membangun Kualitas Bangsa dengan Budaya Literasi. Prosiding Seminar Nasional Bulan Bahasa, Bengkulu, 15 Desemberr 2015. Hal 146-156.

Pujiono, Setyawan. 2012. Berpikir Kritis dalam Literasi Membaca dan Menulis untuk Memperkuat Jati Diri Bangsa. Prosiding Seminar PIBSI XXXVII, Purwekerto 30-31 Oktober 2012. Hal.778-783.

Saptodewo, Febrianto. 2014. Desain Infografis sebagai Penyajian Data Menarik. Jurnal Desain, 1 (3) : 193-198. 